$1-1-1997$

\title{
Metropolitan Growth and the Local Role in Surface Water Resource Protection in the Lake Erie Basin
}

Wendy A. Kellogg

Cleveland State Universithy, w.kellogg@csuohio.edu

Follow this and additional works at: https://engagedscholarship.csuohio.edu/urban_facpub

Part of the Environmental Health and Protection Commons, Urban Studies and Planning Commons, and the Water Resource Management Commons

How does access to this work benefit you? Let us know!

Publisher's Statement

(C) 1997 Elsevier

\section{Original Citation}

Kellogg, W. A. (1997). Metropolitan Growth and the Local Role in Surface Water Resource Protection in the Lake Erie Basin. Journal of Great Lakes Research, 23(3), 270-285. doi:10.1016/

S0380-1330(97)70911-0

\section{Repository Citation}

Kellogg, Wendy A., "Metropolitan Growth and the Local Role in Surface Water Resource Protection in the Lake Erie Basin" (1997). All Maxine Goodman Levin School of Urban Affairs Publications. 012366.

https://engagedscholarship.csuohio.edu/urban_facpub/66

This Article is brought to you for free and open access by the Maxine Goodman Levin School of Urban Affairs at EngagedScholarship@CSU. It has been accepted for inclusion in All Maxine Goodman Levin School of Urban Affairs Publications by an authorized administrator of EngagedScholarship@CSU. For more information, please contact library.es@csuohio.edu. 


\title{
METROPOLITAN GROWTH AND THE LOCAL ROLE IN SURFACE WATER RESOURCE PROTECTION IN THE LAKE ERIE BASIN
}

\author{
Wendy A. Kellogg, Cleveland State University
}

\begin{abstract}
Local governments can play an important role in protecting surface water resources through their compliance with federal and state regulations and through their own land use planning and management practices. Despite 30 years of water quality initiatives in the Lake Erie basin, nonpoint source runoff from urban and urbanizing lands remains a problem. Loss of riparian corridor integrity is increasing as urban areas in the Lake Erie basin experience areal growth. The use and management of land, predominantly a local responsibility, directly affects surface water resources. The role that local governments play in protecting surface water resources was studied in Cuyahoga County, Ohio, the core of the greater Cleveland area. Zoning, building, subdivision, and health ordinances of local governments were reviewed and analyzed. Local governments were then asked to indicate their current planning and management techniques for surface water protection. Overall, protection of surface water resources in the county is inadequate. Local jurisdictions infrequently use the innovative planning mechanisms and water resource management practices suggested by state and federal water resource agencies and organizations. The uneven and fragmented land management system, if replicated in adjacent counties that are now urbanizing, bodes ill for Lake Erie's near-shore water quality.
\end{abstract}

\section{INTRODUCTION}

Land use in the Great Lakes basin is a mixture of agriculture, forest, and urban. In the Lake Erie basin large metropolitan areas and more densely populated urban and suburban areas line the lake's shore. The southern U.S. shore contains several large urban centers, including Buffalo, New York, Erie, Pennsylvania, Cleveland, Ohio, Toledo, Ohio, and Detroit, Michigan. Despite loss of population and industrial resources, these urban areas have experienced low density areal spread, or urban sprawl, in the last 35 years. Careless urban land development adversely affects surface water resources. It increases flooding, increases nonpoint source water pollution, and degrades the integrity of head water streams and riparian corridors (Curtis 1973, Devilbiss 1994, USEPA 1994). Urban population centers contribute conventional biological pollutants, heavy metals, phosphorous, toxic organic chemicals, and

\footnotetext{
*Corresponding author. E-mail: wendy@wolf.csuohio.edu
}

contaminated sediments to the lake (IJC 1982, 1987).

Federal, state, and local governments share responsibility for implementing land use and nonpoint source runoff controls key to addressing these pollution problems. The importance of the local role stems from three conditions: 1) the authority for land use and management practices will likely remain with local governments and private land holders; 2) policy trends at the federal government level emphasize devolution of activities to state and local governments; and 3) water resource managers are shifting to watershed-based water quality management frameworks, which increases the importance of land use as a surface water resource management tool.

Given these conditions, knowledge of how local urbanizing jurisdictions (part of the metropolitan built-up area) manage surface water and land is essential. What strategies and mechanisms do local jurisdictions use to manage their surface waters? To what extent do local governments use resource-ori- 
ented or planning and land use mechanisms? To what extent do local governments coordinate their actions with other entities that affect surface water conditions? This paper explores these questions through a case study of the current status of local water and land management practices affecting surface water resources in Cuyahoga County, Ohio, the greater Cleveland metropolitan urban area. I first describe the management and planning context for local governments in the Ohio Lake Erie basin. A description of the case study site and the research methods precedes a discussion of results and their implications for strategies to improve local government participation in protecting Lake Erie's water quality.

\section{GREAT LAKES WATER RESOURCES AND LAND DEVELOPMENT}

The pattern of urban development typical during the post World War II era-low density, separated residential and commercial land uses, automobiledominated transportation infrastructure (Kuntsler 1993)_placed significant stress on the quality of the human environment and natural ecosystems. The natural flow of water was disrupted by such land development. Small streams were often filled during subdivision development. Soil erosion increased as a result of careless construction practices that stripped vegetation and graded away the natural topography of development sites. Impervious surfaces replaced forests, woodlots, and pastures, increasing the volume of water runoff and degrading its quality. Stream bank erosion increased, especially during storm events. Flood levels and frequency increased as well (Keyes 1976). Land development added pollution to surface waters from nonpoint runoff from streets, parking lots, and homes. Such development severely impaired the function of aquatic ecosystems as river and stream corridors were changed or destroyed (Binkley et al. 1975, Godschalk et al. 1978, Calthorpe 1993, Kivell 1993, Beatley 1994).

In 1972, the International Joint Commission's (IJC) Pollution from Land Use Activities Reference Group (PLUARG) investigated the relationship between Great Lakes pollution and land use activities. PLUARG found that loadings of phosphorus, mercury, lead, pesticides, PCBs, mirex, microorganisms, sediment, and chlorides into the basin were increased by existing land management practices. In a set of representative watersheds, various urban and rural land use categories were analyzed for their annual unit area loads $(\mathrm{kg} / \mathrm{ha} / \mathrm{yr})$ of suspended solids, phosphorus, nitrogen, lead, copper, zinc, and chloride. Developing urban land, although a smaller percentage of total land use in the basin, was found to contribute higher levels of four of these pollutants per hectare than all other uses except irrigated agriculture. Developing urban land contributed $27,500 \mathrm{~kg} / \mathrm{ha} / \mathrm{yr}$ of suspended solids, greater than any other land use by a factor of almost 5 . Total phosphorous loadings from developing urban land contributed $23 \mathrm{~kg} / \mathrm{ha} / \mathrm{yr}$. The contributions of phosphorous from other uses ranged from .02 to 9.1 $\mathrm{kg} / \mathrm{ha} / \mathrm{yr}$. A similar pattern was found for nitrogen, where developing urban lands contributed 63 $\mathrm{kg} / \mathrm{ha} / \mathrm{yr}$ compared to up to 42 for general agriculture, and up to 43 for cropland (PLUARG 1978:52). The PLUARG results were mirrored by other later studies, which found that urban runoff accounts for $65 \%$ of stream pollution and $76 \%$ of lake pollution in metropolitan areas of the United States (Thompson 1989).

The built form of post-World War II urbanization characterizes land use development patterns in Cuyahoga County, Ohio as well. The county population in 1950 was $1,389,456$; in 1960, 1,647,895; in $1970,1,720,835$ (U.S. Bureau of the Census 1962, 1977). Cleveland's first and second rings of suburbs grew in population during this time as the city's population decreased. By 1980 , county population had fallen to $1,498,400$ (U.S. Bureau of the Census 1980) and by 1990 , to $1,412,140$ (U.S. Bureau of the Census 1990). Despite an overall loss of population, the urbanized area of Cuyahoga County continued to spread outward over the last 20 years. Population shifted from the City of Cleveland to the adjacent and then outlying suburbs, and is now shifting again to the six counties surrounding Cuyahoga (Fig. 1).

Conversion of land from farm and village to urban uses caused alarm for some land use professionals in the region as early as 1948. In that year the Cuyahoga County Regional Planning Commission warned that trends in residential building and roads were spreading population outward from Cleveland in an inefficient, wasteful pattern. The Commission's study estimated that the population of 635,000 families they expected by 2000 could comfortably live on $3 / 4$ of the land in the county. Instead, urban development spread "thinly" over the entire county (Beach 1994:9).

In the face of these regional changes, what happened to surface water resources in Cuyahoga County? Ever-spreading urban land development 


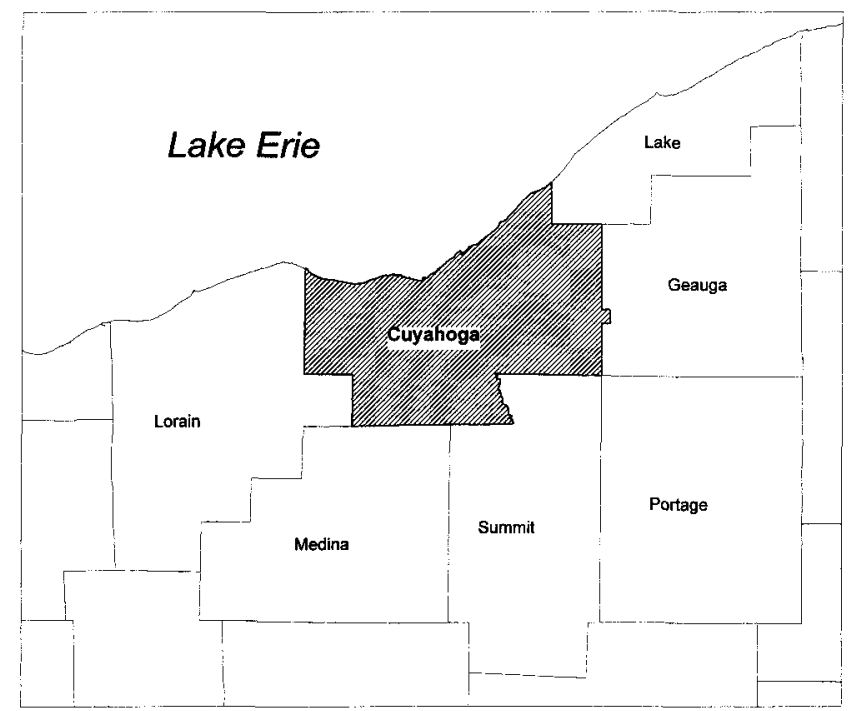

FIG. 1. The greater Cleveland-Akron, Ohio metropolitan areas by county boundaries.

has severely degraded the region's streams and rivers. A recent briefing paper notes that urban runoff in Cuyahoga County contributes half a million pounds of phosphorous, over 6 million pounds of organic matter, 20,000 pounds of lead, 85,000 pounds of zinc, and 20,000 pounds of copper to the county's major tributaries and to near-shore Lake Erie each year. Urbanization of the natural landscape accounts for most of this pollution burden (Cameron 1995).

The 1992 Ohio Water Resource Inventory noted that the leading causes of partial and non-attainment of the state's river and stream water quality standards were organic enrichment, siltation/sedimentation, and habitat modification. Land use activities associated with urbanization are considered the greatest threat to the health and well-being of headwater streams and significantly contribute to these problems. The state report considers land use policies and the presence of a riparian buffer zone the two most important covariates determining the ability of streams to support aquatic life (Ohio EPA 1994) .

\section{INSTITUTIONAL ASPECTS OF SURFACE WATER RESOURCE MANAGEMENT}

In most metropolitan regions in the United States today, the condition of surface water resources is affected by a loose network of multiple levels and types of governments, organizations, and private citizens (Croke et al. 1973, Schueler 1994). This network is characterized by a fragmentation of responsibility and authority. Federal and state agencies have responsibility for enforcing water quality regulatory programs and for developing water resource management guidelines. Local governments retain land use regulatory authority. No one entity is responsible for all conditions that affect the use and quality of surface water resources, creating a fragmented action space (Lang and Brooks 1987). Interaction among these organizations varies greatly, depending in part on whether interaction is mandated by law or voluntary. Variability in local priorities, political culture, and technical capabilities affect local participation significantly.

An ideal model of surface water planning and management is comprehensive and integrative in terms of knowledge, decision making, and implementation (Simonds 1978, Steiner 1991). Planning and management is done at the watershed-scale, incorporating a multi-media and watershed-ecosystem knowledge base (Great Lakes Science Advisory Board 1978, Royal Commission 1992). If we assume that formation of a super-unit of government is unlikely in most metropolitan regions in the United States, a more integrative, watershed-based approach would be implemented in a loose organizational network characterized by fragmented authority and high variability in technical and organizational resources. This model more closely mirrors existing institutional arrangements in most metropolitan regions in the United States. Under such conditions, both the level of coordination among organizations and the unilateral actions by local governments significantly affect surface water resources.

A watershed-based approach to surface water management would be based on coordination among parties responsible and capable of affecting surface water resources. Using a coordination model, the network of parties would develop systems for sharing information and for concerted decision making. Each jurisdiction, agency, or non-governmental organization would adjust policies to reflect any collaborative decisions. Participation in this approach could be justified on expectations that coordination would result in superior decision making outcomes (less nonpoint source pollution, less frequent and damaging floods, etc.). The model assumes that each participant would accrue increased benefits from its collaborative participation (Molnar and Rodgers 1982) and that some redundancy and competition in man- 
agement responsibilities might lead to better and more accountable performance (Bendor 1985, Molnar and Rodgers 1982).

Such a model has been adopted to some degree in the Great Lakes basin, where information exchange has been spurred by the Great Lakes Water Quality Agreements and its various programs. Still, surface water pollution from urban nonpoint sources remains problematic. To what degree are local governments participating or coordinating with other jurisdictions and agencies when making land use decisions that will affect the condition of surface waters? The next pages review the most relevant coordination-based initiatives affecting Lake Erie's watersheds and the role of local governments.

\section{Coordination-Based Initiatives}

\section{PLUARG}

The 1978 PLUARG report urged development of a comprehensive strategy to reduce nonpoint source loadings, but found that local urban development programs in general were not considering water quality problems. The report urged that governments

make better use of existing planning mechanisms ... insuring that developments affecting land are planned to minimize the inputs of pollutants to the Great Lakes; and . . . insuring that planners are aware of and consider PLUARG findings in the development and review of land use plans ... . [and place] greater emphasis ... on the preventive aspects of laws and regulations directed toward control of nonpoint pollution (PLUARG 1978: 72-74).

The report recommended education of urban officials to demonstrate the relationship between their areas of responsibility and water quality problems and recommended implementation of programs to encourage local units of government to develop storm water management and sedimentation controls. Implementation of the PLUARG report recommendations was minimal. A 1983 report issued by the IJC Water Quality Board's Nonpoint Source Control Task Force concluded that the governments of Canada and the US "had made no formal response to the recommendations of PLUARG . . . regarding pollution from land use activities, neither country had undertaken comprehensive programs to combat nonpoint sources, ... [and] urban sources of nonpoint pollution had received very little attention" (Nonpoint Source Pollution Control Task Force 1983).

\section{RAPS}

Some progress toward including pollution from land use has been made in developing Remedial Action Plans for the basin's Areas of Concern. Some RAPs have adopted a watershed-based framework as part of their adoption of an ecosystem approach recommended by the International Joint Commission, but integration of land use concerns has been inconsistent across the RAP program (Kellogg 1993). In Ohio, the Remedial Action Plan process for the Cuyahoga River has been underway for several years. Until recently, there has been no concerted outreach effort aimed at local decision makers and planners. Recently, however, the RAP coordinating committee has begun an initiative at the Big Creek sub-basin level that includes outreach to local decision makers concerning land use and nonpoint source pollution (Personal Conversation with Kelvin Rodgers, Cuyahoga River RAP Coordinator, February 15, 1997).

\section{LaMP}

The Lake Erie Lakewide Management Plan (LaMP), begun in 1993, will include recommendations for specific programs or actions for nonpoint sources of a set of critical toxic pollutants. The State of Ohio is acting as the lead state level agency for the Lake Erie LaMP, and public advisory and technical committees have been convened for the program. The states and federal governments with jurisdiction in the Lake Erie basin have developed initial loading estimates for the critical pollutants (USEPA 1993a). A recent Ohio EPA summary of the LaMP notes that the plan's binational management committee will be formed of "senior-level managers from Federal, Provincial, State and Tribal governments with responsibility for water quality, fish and wildlife, agriculture, human health, research, and land-use planning" (Ohio EPA 1997). Land use planning is not done at these levels of government, however, in Great Lakes states.

United States federal initiatives are based on a combination of mandates and incentives designed to stimulate cooperative efforts between levels of government. Results have been mixed, however. 


\section{Clean Water Act}

PLUARG had anticipated that in the United States, "preparation of Section 208 water quality management plans ... [would] provide a firm basis upon which to develop solutions" to nonpoint source pollution (PLUARG 1978: 72-73). Most of the financial and technical assistance for local communities was spent to improve publicly-owned waste water treatment plants, which dramatically improved water quality in U.S. tributary rivers and streams and in Lake Erie particularly. Although Congress recognized the critical role that local land use planning would play in controlling nonpoint source pollution, Section 208 did not introduce a stronger federal role in land use. It only required that states develop area-wide waste treatment management plans. Section 208 plans were not used to any great degree to address nonpoint source pollution (Boyer 1988), likely because "the political unpopularity of land-use planning shifted the focus again to controlling point source pollution" (Wiltshire 1994:246).

\section{NURP}

Under the National Urban Runoff Program (NURP) between 1979 and 1983, state, county, and local governments in 28 metropolitan areas studied the quality of storm water. In some cities, pollution problems in storm water rivaled or exceeded discharges from point sources (Adler et al. 1993). However, only six of these urban areas were in the Great Lakes Basin. By 1985, USEPA's Nonpoint Taskforce emphasized the management role of states, with USEPA providing technical and financial assistance to state and local governments to implement nonpoint source program (Water Planning Agency 1984:xxi).

\section{WQA}

Passing the 1987 Water Quality Act (WQA), Congress placed requirements on state and local governments to address nonpoint source pollution. Under section 319 , states must work with regional and local governments to manage nonpoint source pollution through development of Water Quality Management Plans. These plans must address priority nonpoint source water quality problems identified by each state and identify the regulatory and nonregulatory mechanisms, activities, and best management practices (BMPs) the agency has selected to control nonpoint source pollution (Wiltshire 1994).

\section{USEPA}

In 1991 the USEPA's Office of Water Policy launched a watershed protection initiative intended to promote use of a watershed approach in all of its own water programs and in its partnerships with other federal, state, and local agencies (USEPA 1993b). A report commissioned by USEPA Region V's Wetlands and Watersheds Section asks local governments to implement land management practices to "compensate for the impact of urbanization on watersheds."

The State of Ohio has several programs relevant to surface water resource protection.

\section{Ohio EPA}

Ohio's Environmental Protection Agency administers the federal WQA programs. The state water and resource agencies offer guidelines on a variety of surface water-related activites. The state requires permits to change the course of surface water (Ohio Revised Code 6151). Ohio is presently developing a set of stream protection guidelines for local governments (Devilbiss 1994) and requires erosion minimization mechanisms during construction periods (Ohio EPA 1994). The state has recently completed its Coastal Management Program to implement the 1972 Coastal Zone Management Act after several years of consultation with local governments and property owners (Ohio DNR 1996).

\section{The Role of Local Government}

Following Steiner, local governments (for our purposes, municipal corporations and townships) can protect surface water quality in three ways: through compliance with and implementation of laws and regulations of federal, state and county governments; through participation in non-mandatory programs offered by these governments; and in the course of locally-based planning and management initiatives. These three participation opportunities are described briefly.

\section{Regulatory Compliance}

Local governments are spending a rising proportion of the total spending for improving surface water quality (Center for the Study of Law and Politics 1993) to meet increasingly stringent federal and state water quality standards (Beach 1993). Local efforts have significantly reduced 
point source pollution, as each local jurisdiction complies with their National Pollution Discharge Elimination System (NPDES) discharge permits for publicly owned treatment works and ensures that industrial pretreatment programs are in effect (USEPA 1994).

Local compliance with nonpoint source pollution requirements is less certain. Many of the BMPs designed to reduce nonpoint source pollution and erosion identified through state participation in the national nonpoint source programs under Section 319 will need to be implemented through local capital improvement programs and planning mechanisms (Wiltshire 1994). The 1987 WQA requires that local governments obtain a discharge permit for storm water and for combined sewer overflow (CSO) outfalls under the NPDES process (USEPA 1995, Dowden and McNurney 1995). However, USEPA has not promulgated Section 319 regulations for larger cities, and recently extended the compliance deadlines for communities less than 100,000 in population until 2001 (Anonymous 1996).

Local governments must institute minimal regulations to protect property and life from flooding to comply with federal flood insurance programs (Griggs and Gilchrist 1983). Local governments must also ensure that any land development complies with requirements regarding fill or disruption of federal and state-designated wetlands (33 U.S.C. $\S 1344)$. Local governments and land owners on the Lake Erie shore in Cuyahoga County must soon modify land development in coastal areas according to a new permit system under the Coastal Zone Management Act and Ohio law (16 USC $\S$ 1456(c)(3); Ohio Revised Code1506).

Finally, when local governments receive federal funding for their own projects, or issue building permits for federally-funded projects, they must comply with requirements for environmental impact assessments required under the 1970 National Environmental Policy Act (NEPA). Some states also require environmental impact assessment by statute or executive order (Godschalk et al. 1978, Visconsi 1994), although Ohio does not impose such requirements universally.

\section{Participation in Incentive and Technical Assistance Programs}

The federal and state governments, regional service districts, and counties offer financial and technical assistance to local jurisdictions to assist them in protecting surface water quality. Regional
USEPA offices and Ohio EPA district offices offer technical assistance to local governments on the NPDES storm water permit process, wetland monitoring and enforcement activities, preparation of NEPA documents, securing and interpreting research data and results, and water quality monitoring (USEPA 1990, Alexander 1993). The United States Department of Agriculture's (USDA) Soil and Water Conservation Service offers technical assistance in the planning, design, and implementation of BMPs for water quality restoration and protection, including erosion control programs (Alexander 1993). The Federal Emergency Management Agency offers technical assistant to local communities on protecting floodplain resources (Federal Interagency Floodplain Management Taskforce 1996). The 1994 National Flood Insurance Reform Act gives statutory authority to the Community Ratings System (CRS), a voluntary program offering decreased insurance premiums to communities that include a review of the natural and beneficial function of the flood plains in the community (Rossmiller 1995).

Ohio's state regulatory and resource management agencies are required by law to provide technical assistance to local governments concerning water pollution control, coastal management, soil and water conservation, flood plain management, and public health to help local governments protect surface water quality (Ohio Revised Code, Chapters 6111, 1521, 1506, 1511, and 3745). Regional and county planning agencies also offer technical assistance to municipalities and township jurisdictions to improve their planning capacity. County planning commissions can assist municipal corporations and townships in preparation of land use and zoning plans, although preparation of comprehensive plans is optional for local governments in the state of Ohio (Ohio Revised Code 7130).

\section{Local Authority}

Local jurisdictions directly shape the natural environment in their communities through their corporate and police powers used to promote and protect the health, welfare, and safety of community residents. Following Steiner (1991), local jurisdictions can influence quality of surface water resources through regulation, spending, and taxation.

Authority to regulate land use, granted through a combination of the community's charter of incorporation and state planning enabling legislation, is a 
key source of the municipal and township role in protecting surface water resources. Local regulation includes land use (zoning ordinances, building codes, subdivision regulations) and determination of land use planning process. The significance of land use for water quality and hydrology has been documented well, beginning in the 1970 s when land use was found to be "the most fundamental" factor determining the quality of the environment by the federal Citizen's Advisory Committee on Environmental Quality (Redding and Parry 1973). Land use planning and management can protect surface water resources most effectively, however, when integrated with environmental assessment and regional approaches (McHarg 1969, Kaiser et al. 1973, Simonds 1978, Yaro et al. 1993, Schueler 1994). Unfortunately, decisions made at the local level are often without regard for the integrity of the whole ecosystem, and can rapidly lead to overall degradation (Odum 1982).

Local governments can also protect surface water resources through their power to spend public monies, either for direct acquisition of land, purchase of development rights or conservation easements, or for infrastructure projects. Finally, local governments can protect environmental quality through their power to tax by guiding land use through tax incentives or disincentives (Baker 1976).

Land planning and management initiatives have been implemented within a loose and fragmented network in the last 30 years in the Great Lakes basin. Despite the range of initiatives and opportunities described above, the State of the Great Lakes report of 1995 advised that "land use and re-use changes associated with urban development of agricultural land and encroachment on wetlands and aquatic habitat continue to have a significantly negative impact on water resources (USEPA/EC 1995:9). To what extent does the role of local governments in Cuyahoga County reflect the status of this loose network of initiatives? What is the unilateral role of local governments in protecting surface water resources? Do local governments coordinate their actions? Do they obtain technical assistance when needed to improve their effectiveness? How well do local governments regulate lands use and carry out land planning processes to protect surface water?

\section{RESEARCH DESIGN}

From the review of existing federal and state level legislation and programs that affect surface water resources presented above, a framework of compliance mandates and program opportunities for local governments was delineated. Because land use decisions are of local purview, a significant level of diversity in the kinds of policies and mechanisms implemented by local jurisdictions was anticipated. Such diversity might reflect differences in community values, economic circumstances, natural and cultural resources, institutional capacity (including the availability and use of technical and planning information and expertise), political will, fiscal resources, and variations in police power embodied in the charters of incorporation for municipalities and townships.

Our data collection sought information about local-level planning processes, regulation, spending and taxation that explicitly or implicitly affect surface water resources. Local regulation of land use and other actions shaping environmental quality are implemented through each jurisdiction's Codified Ordinances. We began by reviewing the zoning ordinances, subdivision regulations, building codes and public health, safety and sanitation regulations of each of the 59 municipal corporations and townships in the county. The zoning and subdivision records were available in hard-copy files at the Cuyahoga County Planning Commission. The building codes, and health, safety, and sanitation regulations were reviewed using files at Cleveland City Hall's Public Administration Library.

A letter was then sent to the mayor of each jurisdiction in the county. The letter contained an explanation of the project and a table summarizing the municipality's current regulations culled from our review at the Planning Commission and City Hall. We asked that the appropriate department verify our information and make updates as necessary. We also included a questionnaire that asked respondents to indicate whether their communities used a variety of other planning or review mechanisms or procedures, whether they had received technical assistance or financial assistance from other governments or agencies in the last 5 years and for what, and the level of importance placed on environmental quality and environmental issues in their community. Municipalities and townships were telephoned 3 weeks later to prompt return of the questionnaire. Two rounds of additional conveyance of the questionnaire by facsimile were carried out for those jurisdictions that did not respond, followed by additional telephone calls asking the jurisdiction to return the questionnaire. In all, 37 of the 59 municipal and township jurisdictions responded. 


\section{FINDINGS}

We discovered a wide range of ordinances with direct and potentially indirect effects on surface water resources. We sorted the ordinances into a set of six resource/physiographic categories and five planning/land use categories of mechanisms that would affect surface water resources.

\section{Resource/ Physiographic Protection Mechanisms}

Table 1 summarizes the frequencies with which local governments used mechanisms in the six categories that address water resources or physiographic characteristics (erosion control, grading/excavation, flood plain control, preservation of topography, surface water quality, and surface water flow/hydrology). Local jurisdictions use grading/excavation requirements, erosion control, and flood plain control most frequently $(39,33$, and 37 jurisdictions, respectively). Erosion control and grading/excavation requirements typify standard building and subdivision regulations, although there was considerable variety in the scope and application of these ordinances and their requirements. The frequency of flood plain controls can be attributed to existing federal insurance program requirements with which all local jurisdictions participating must comply. Twenty four of the 59 municipalities have ordinances protecting the natural topography of the land, a category which moves significantly beyond protecting health, safety, and welfare of community residents to protecting natural features. The majority of the 24 communities that have passed ordinances protecting natural topography are either located in the east or southern side of the county (where a hilly terrain predominates), are located adjacent to Lake Erie (where lake front bluffs domi-

\section{TABLE 1. Number of communities in Cuyahoga County using mechanisms in resource / physio- graphic categories to protect surface water resources.}

\begin{tabular}{lc}
\hline \hline RESOURCE / PHYSIOGRAPHIC & $\mathrm{N}=59$ \\
\hline Erosion Control & $\#$ \\
Grading/Excavation & 33 \\
Flood Plain Control & 39 \\
Preservation of Topography & 37 \\
Surface Water Quality & 24 \\
Surface Water Flow/Hydrology & 6 \\
\hline
\end{tabular}

nate), or have significant surface water formations shaping the contours of the land.

The infrequency of ordinances explicitly focused on surface water quality might stem from local perception that state and federal permit discharge programs are regulation enough. Only 21 jurisdictions have ordinances regulating surface water "flow" or "hydrology." The infrequency of ordinances focused on surface water flow is troubling, considering the State of Ohio's requirements that construction processes do not result in excess offsite water flow. Many jurisdictions have no local ordinances or other regulations for these two categories, yet ultimately it is local building and subdivision regulations and their enforcement that will ensure successful implementation of the state policy. Municipalities that have adopted stream-corridor protection regulations have done so voluntarily, often through the guidance and catalyst provided by the county Soil and Water Conservation District agent.

During data collection, we discovered a wide range in the scope and likely effectiveness of ordinances within the resource/physiographic categories. Each municipality's approach was ranked to portray more accurately the current status of these mechanisms and to begin to understand the expected level of overall effectiveness. Protection mechanisms were evaluated according to three criteria:

- Watershed-based-the ordinance promotes functional integrity of the land/water system

- Coordination - the ordinance promotes collaboration and exchange of information among government agencies and stakeholders

- Local Initiative - the practice goes beyond state/federal requirements

Based on these criteria, decision rules for a low and high rank were developed for each of the six protection mechanisms. Table 2 presents these rules.

For each category the ordinance of a community was ranked by two project team members to check the reliability of the decision rules and ranking definitions. A rank of "low" was then assigned 1 point; a rank of "high," 2 points. Scores for each of the six categories were summed to give each community an overall score designating the community's management system for surface water protection. Jurisdictions were placed in three levels of surface water resource protection-low, medium, and high-ac- 
TABLE 2. Decision rules for ranking surface water resource protection mechanisms adopted by local jurisdictions in Cuyahoga County.

\begin{tabular}{|c|c|c|}
\hline Mechanism & Low & High \\
\hline Erosion control & $\begin{array}{l}\text { reseeding, replanting, or other ground } \\
\text { cover within a specific period after } \\
\text { construction }\end{array}$ & $\begin{array}{l}\text { submit plan for erosion control prior to } \\
\text { construction, coordination with other agencies } \\
\text { for technical assistance, or tie erosion control to } \\
\text { other environmental conditions }\end{array}$ \\
\hline $\begin{array}{l}\text { Grading or } \\
\text { excavation }\end{array}$ & $\begin{array}{l}\text { permit to conduct grading according } \\
\text { to standard engineering practices }\end{array}$ & $\begin{array}{l}\text { site integrity maintained, including attention } \\
\text { to features such as trees, water flow, topsoil condi- } \\
\text { tions and topography }\end{array}$ \\
\hline $\begin{array}{l}\text { Surface } \\
\text { quality }\end{array}$ & absence of regulations & $\begin{array}{l}\text { regulations prohibit water polluting, dumping, } \\
\text { littering or unwhole-some use of surface water }\end{array}$ \\
\hline Surface water flow & $\begin{array}{l}\text { prohibits obstruction or diversion of } \\
\text { natural flow }\end{array}$ & $\begin{array}{l}\text { requires maintenance of some specified } \\
\text { buffer area around water course }\end{array}$ \\
\hline $\begin{array}{l}\text { Preserve natural } \\
\text { topography }\end{array}$ & absence of ordinance & $\begin{array}{l}\text { minimal alteration of the natural topography at } \\
\text { time of land development }\end{array}$ \\
\hline $\begin{array}{l}\text { Flood plain } \\
\text { control }\end{array}$ & $\begin{array}{l}\text { meets requirements of federal } \\
\text { flood insurance programs }\end{array}$ & $\begin{array}{l}\text { exceeds federal requirements: restricts types } \\
\text { of use in flood plain, expands area covered or re- } \\
\text { quires more stringent building standards }\end{array}$ \\
\hline
\end{tabular}

cording to these summations. Figure 2 presents the spatial distribution of these levels in Cuyahoga County.

Communities now experiencing intense land development tended to rank higher in our system, largely due to their more stringent requirements for erosion control and preservation of natural topography during construction. This outcome most likely stems from several factors. We would expect communities at the county's outer edge presently experiencing land development today to have more restrictive controls than those whose land is by and large developed. These currently-developing communities benefit from knowledge of past experiences, greater available information about the environment, and more numerous and strict requirements from state and federal governments. The communities with the highest rankings are also almost all adjacent to one of the three major rivers in the county: the Rocky, the Cuyahoga, and the Chagrin (Fig. 2). These river-corridor communities have been influenced to directly protect surface water by two regional park agencies. The Cleveland Metroparks oversees a set of regional parks, with three parks in the Rocky River basin, three parks in the Cuyahoga River basin, and two parks in the Chagrin River basin within Cuyahoga County. The Cuyahoga Valley National Recreation Area, administered by the National Park Service, encompasses part of another community in the county in the Cuyahoga River basin. Both these park organizations have outreach programs to communities adjacent to their administrative areas. The unique presence of these park systems has most positively influenced the communities at the fringe of the county. These communities have also been targeted by regional Soil and Water Conservation District staff.

Despite these relatively stronger surface water management efforts, the high level of variability within each watershed is troubling. Beginning at the most "upstream" section in each river basin within the county, we see varying levels of effort to protect surface water quality. The effects of a higher level of protection by an upstream community can be minimized as the river runs through less protected areas in downstream communities. Significant tributary water courses, both small and large, remain much less well protected in communities that ranked "low" on our scale (see for example, the lower reaches and tributaries of the Cuyahoga River). None of the communities studied has a comprehensive surface water management approach or policy, however. Even the relatively stronger effort by the upstream communities is troublesome, for hundreds of acres of land are converted from rural to urban each year in these communities. The variability in management 


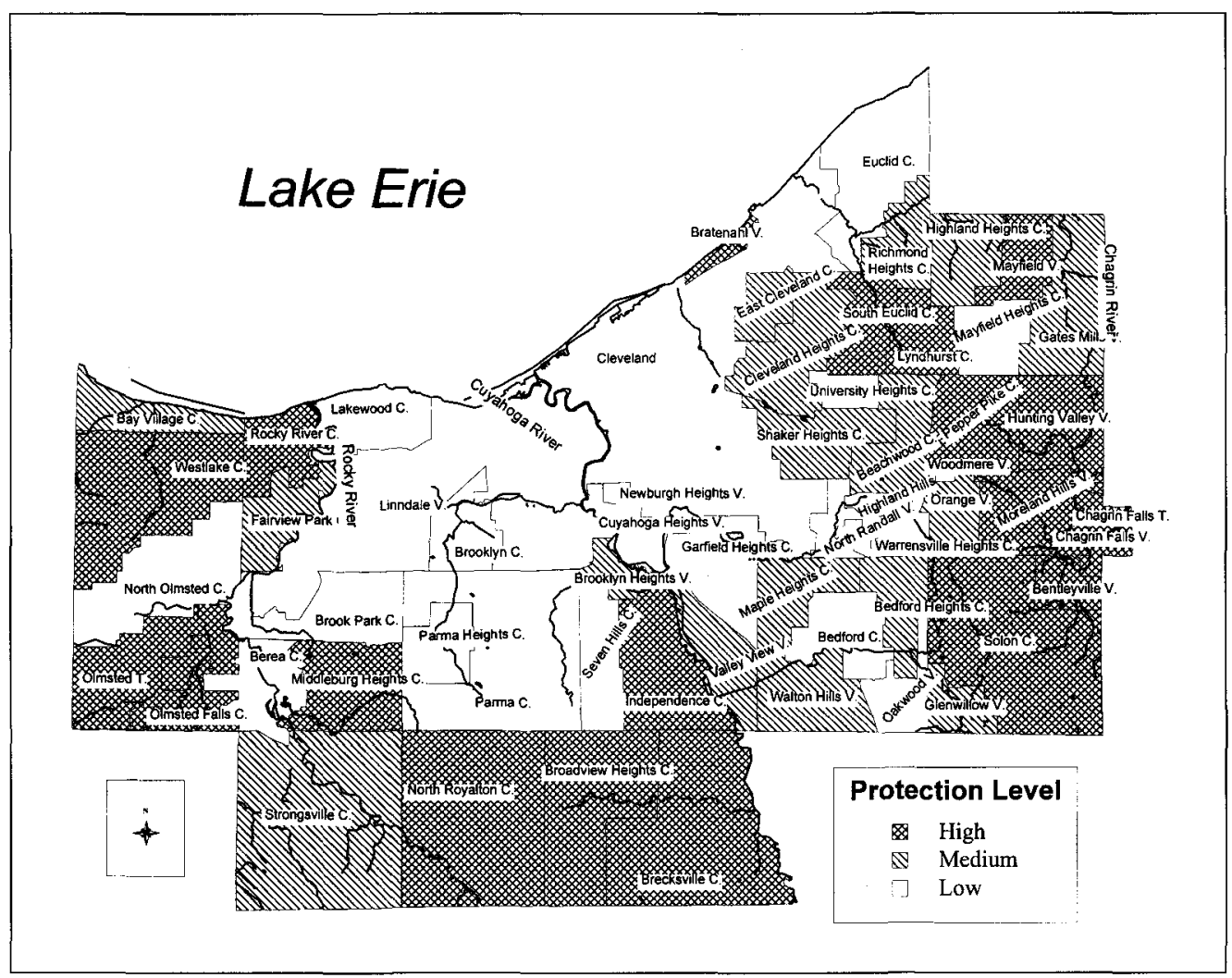

FIG. 2. Relative strength of combined resource/physiographic protection mechanisms, by municipal jurisdiction.

approaches and the volume of land conversion regulated by the upstream communities diminishes the overall quality of the water entering Lake Erie.

\section{Planning and Land Use Protection Mechanisms}

Relatively few local jurisdictions in Cuyahoga County have ordinances which exemplify more innovative zoning and subdivision practices used in many communities to protect surface water resources : cluster development, open space, overlay zoning, performance standards, and planned unit development (PUD). Cluster development ordinances allow or require reservation of open areas around buildings. In a subdivision, for example, housing would be "clustered" in close proximity on smaller lots and a large potion of the subdivision acreage would be left free from buildings, roads, or parking areas. An open space ordinance can refer to building placement, such as in a cluster development, or can set aside larger areas of land to preserve green space or habitat areas. Both these mechanisms can maintain vegetated surfaces, which absorb and filter rain water, decreasing surface runoff (compared to parking lots and roofs) in storm events, and minimizing nonpoint source pollution. An overlay zone is designated as a special land use category, and generally supersedes existing zoning requirements. Communities can create riparian corridors using an overlay zone, for example. Performance standards can be assigned to any type of land zoning to ensure that use of the property meets appropriate levels of impact. For example, land developers could be required to maintain post-construction off-site water flow to within $5 \%$ of pre-construction rates. A planned unit development (PUD) is a special land use zone that allows a mix of land use types and foregoes many traditional requirements. Site design is negotiated between the developer and the community's planning department. For example, a developer might be allowed additional building height or density in exchange for including a storm water retention basin to accommodate both a new subdivision and an adjacent older neighborhood. Table 3 summarizes the fre- 
TABLE 3. Number of communities using planning mechanisms for surface water protection.

\begin{tabular}{lc}
\hline \hline & $\mathrm{N}=59$ \\
PLANNING / LAND USE & $\#$ \\
\hline Cluster Development & 7 \\
Open Space & 20 \\
Overlay Zoning & 5 \\
Performance Standards & 28 \\
Planned Unit Development & 16 \\
\hline
\end{tabular}

quency at which these types of mechanisms are used in Cuyahoga County.

Only performance standards (28 of 59) and open space (20 of 59) mechanisms were used at any meaningful level. However, performance standards were most often used to address on-site noise; open space ordinances in the majority concerned lawn and landscaping areas around condominiums and townhouses. Despite their potential for protecting water recharge areas and riparian corridors, use of cluster development, overlay zoning, and PUDs are minimal in the county. The low frequency of these types of mechanisms is most likely a direct result of two interrelated conditions: local reluctance to pass innovative planning mechanisms and the status of state law. As Jacobs (1989) has described, strong traditions of local autonomy severely limit the state role in local land use decision making, for environmental purposes or otherwise, and this condition certainly exists in Ohio. The state planning enabling legislation in Ohio does not require that local jurisdictions develop comprehensive or master plans. Communities can therefore designate land use through zoning ordinances without consideration of broader natural resource issues.

Equally significant, some local leaders consider land regulation for environmental purposes a detriment to economic development. As part of their responsibilities to serve the public, local government leaders in Cuyahoga County consider commercial, residential, and industrial development as their most important priority. Many of these leaders have not responded to growing recognition by citizens that the areal growth occurring at the outer edges of the county is having an adverse effect on community liveability and environmental quality. Moreover, according to one regional public employee interviewed, decision makers in some local jurisdictions who accept the need for stronger environmental protection are reluctant to pass more innovative zoning ordinances because of fear of legal action alleging a "taking" by land owners and land developers.

From the inventory and analysis, we see a great variety in the kinds of surface water resource protection mechanisms and the frequency of their application. The uneven protection across the county is made even more clear by the analysis of the relative strengths of the particular ordinances within each category presented above. Enforcement of existing mechanisms is a problem as well, according to one regional technical staff person, as regulations are unevenly applied to construction practices and issuance of building permits.

\section{Policy and Process Mechanisms}

Table 4 summarizes the responses from the questionnaires $(\mathrm{N}=37)$. We see that for every question except whether the jurisdiction included environmental considerations in any kind of community plans (19 of 37), few communities responded positively to the use of a set of planning and policy processes regarding environmental quality. Most of the communities accepting financial assistance ( 9 of 37) applied it to improvements in point source reduction. However, when asked to rank the level of importance their community places on environmental quality as part of its decision making, 24 respondents indicated "very important," and 9 indicated "somewhat important." Despite the relatively low frequency of land management, planning and policy process mechanisms, 33 of the 37 respondents indicated that environmental protection was important. This response indicates at minimum a strong dissonance between regulatory and planning implementation and the perception of environmental managers in the mayor's office or executive departments.

\section{TABLE 4. Frequency of questionnaire responses.}

\begin{tabular}{lcrcc}
\hline \hline & & & \multicolumn{2}{c}{$\mathrm{N}=37$} \\
\hline Mechanisms/Processes & no & yes & nr & \\
\hline Use Tax Incentives & 33 & 3 & 2 & \\
Use Spending Policies & 30 & 5 & 2 & \\
Plan Elements & 16 & 19 & 2 & \\
Environmental Review & 30 & 6 & 1 & \\
Financial Assistance & 27 & 9 & 1 & \\
Technical Assistance & 30 & 6 & 1 & \\
Brownfields Assistance & 31 & 4 & 2 & \\
& & & & \\
Values & not & some & very & nr \\
\hline Importance of Environ. & 2 & 9 & 24 & 2 \\
\hline
\end{tabular}




\section{Summary}

The current status of local jurisdiction efforts leads to fragmented and uneven protection of surface water resources in Cuyahoga County. Our results reflect problems in all three areas of local action: compliance, participation in state and federal programs, and local initiative.

\section{Compliance}

How well can local governments be meeting requirements of federal law concerning surface water with this kind of management and planning framework in place? The infrequent use of planning and resource mechanisms well-regarded to address nonpoint source runoff raises serious concern, as localities will need to increase their implementation of best management practices. The large range of strength within mechanism categories means that despite ordinances "on the books," high uncertainty exists in how well surface water resources are protected from nonpoint source pollution, especially pollution generated during construction activities.

\section{Local Participation in Federal, State, and County Technical Assistance Programs}

Despite the existence of numerous federal, state, and county technical assistance programs, few municipal and township governments reported using them. One of the most important components when protecting surface water resources is a regional or watershed perspective. All the local jurisdictions in Cuyahoga County are within the Lake Erie drainage basin, either as part of the Cuyahoga, Rocky, and Chagrin rivers watersheds or as part of the Lake Erie shoreline drainage area. The County Planning Commission staff, the Soil Conservation District, and the Cleveland Metroparks have spent much time and resources on outreach and technical assistance to build a more regional perspective. The agencies provide data and model ordinances that could be used by local jurisdictions for protecting surface water resources. Adoption of these model ordinances would tend to minimize the uneven effectiveness between communities in the watersheds. Most jurisdictions in the county have not adopted these model ordinances, however. The low response when questioned about receipt of "outside" technical assistance would indicate that required efforts to include local governments in developing nonpoint source management plans by Ohio's state agencies are either not reaching local governments, or not well-known in the local chief executive's office or by municipal staff.

\section{Local Initiative}

Whether local jurisdictions coordinate their actions with others in their watersheds or not, their unilateral actions remain predominant because legal authority for land use control remains at the local level. The results concerning planning and policy mechanisms appear to reflect a problem limiting the effectiveness of the "land guidance system" at the local level that Croke et al. (1973) identified-an uncertain relationship between surface water protection and community land use planning. Quite frequently, the building codes and zoning ordinances within one jurisdiction contradicted each other. The questionnaires were often forwarded to a contract attorney for responses. Many jurisdictions in the county have no planning department to initiate proactive planning for surface water protection. The Cuyahoga County Planning Commission staff assists communities in developing land use plans or master plans, but either these plans are not done or the plans do not tend to contain environmental protection elements in most communities judging from responses to the questionnaire. Again, only 19 of 37 responding jurisdictions include an element in their planning that focuses on environmental conditions. Only 6 of the jurisdictions have an ordinance requiring some form of environmental review process for land development. These results directly reflect the absence of state level requirements in Ohio for community planning, environmental planning, and environmental review processes that can help communities identify important resources and avoid land use practices that degrade surface waters.

The potential for local coordination to address surface water problems manifest at the regional scale through compatible land use practices is at this time low. Despite availability of technical assistance and model ordinances for surface water protection from regional and state agencies, we found an extremely high level of variability among jurisdictions. High variability will make it more difficult to reconcile land use planning practices among jurisdictions, a needed step for addressing surface water protection on a watershed basis.

The status of planning and coordination mitigate strong local environmental initiative, either unilaterally or in concert, to address nonpoint source pollution and flooding on a watershed, land use basis. Strong participation by local jurisdictions in water- 
shed-based efforts requires that each jurisdiction establish protection of surface water resources as a political priority and develop strategies and mechanisms to achieve it. We are uncertain whether other political priorities or inadequate staff and organizational resources have impeded some local jurisdictions in carrying out these actions.

The present state of affairs in Cuyahoga County does not bode well for Lake Erie water quality as it is affected by the urban areas on the north coast of Ohio. Cuyahoga County is the largest metropolitan area in the Ohio Lake Erie basin, and despite population stabilization, it is still expanding outward. The greater Cleveland area is reaching out to Akron to the southeast, Lorain/Elyria to the west, and Painesville/Mentor to the east. By the year 2050, analysts expect that the urbanized areas of Cleveland-Akron-Lorain-Painesville will meld into one. As these settlements expand over the rural landscape, they will trigger additional degradation in the head water areas of the three rivers flowing through Cuyahoga County. Whether these counties and local jurisdictions manage urban development to protect their surface water resources is a critical factor influencing ongoing efforts to improve Lake Erie's water quality.

\section{RECOMMENDATIONS AND FURTHER RESEARCH NEEDED}

What we see in Cuyahoga County is the result of a series of fragmented and sometimes very loosely coordinated activities for surface water resource management. As described above, the action space has been created by the plethora of local, state, and federal regulations. These needs are evident:

- improved regulatory context within which local governments operate to increase the likelihood that they will coordinate policies and planning efforts with other jurisdictions and agencies

- increased local capacity and willingness to manage surface water resources wisely in unilateral actions

\section{Mandated Coordination}

Increased inter-jurisdictional cooperation is essential for building surface water protection programs at the watershed level. A National Resources Defense Council (NRDC) report on Cuyahoga County's surface waters concluded that nonpoint pollution was not being addressed because of the fragmentation of local authority (Cameron 1995). Several strategies can be adopted to require coordination.

The State of Ohio should pass environmental impact assessment and land use legislation. Ohio currently has no comprehensive environmental review statute (Jessup 1990, Hall 1991, Visconsi 1994) and no state-level land use planning act. State level requirements for environmental impact assessment and comprehensive land use planning can be an effective mechanism to encourage local participation in state, regional, and county coordination of surface water protection (Goldshalk et al. 1978, Gale 1992). The state should require that local jurisdictions complete comprehensive planning processes, with a mandatory environmental quality element, prior to adoption of zoning ordinances. Such a measure would increase the level of forethought communities give to environmental quality in general and surface water more particularly. The state should also review township charters, which limit the authority of townships to narrow health and public safety purposes when zoning land.

State-level legislation should also require state agencies to develop environmental impact assessments for their own large-scale projects. Urbanizing land development results in part from federal and state highway construction policies that allow commuters to live ever-increasing distances from the urban core while maintaining desirable commuting times. State highway policies encourage degradation of surface water resources and should be examined carefully for their impacts on the location and rapidity of land development and its affect on watershed resources.

\section{Collaboration Incentives and Local Action}

The state and federal agencies in the region must do more to build effective partnerships with local governments so these jurisdictions can more ably collaborate with each other and appreciate the importance of protecting surface water resources. These partnerships are particularly important in the headwater jurisdictions currently experiencing rapid land development. Our questionnaire indicated that despite the existence of many technical assistance programs, local governments rarely utilize them. State, regional, and county governments should assess their technical assistance programs to identify why local governments do not take advantage of existing programs more fully and how effective 
these programs are for protecting surface water resources if utilized.

Several areas of technical assistance that exist should be vigorously implemented. The State of Ohio should complete, promulgate, and vigorously promote adoption of its guidelines for stream corridor protection at the earliest opportunity. Care should be taken that these guidelines do not conflict with, but reinforce USEPA programs and guidelines. The state should consider making the stream corridor protection program mandatory.

The state and county should create or enhance outreach to local decision makers (city and town councils) and citizens to encourage an appreciation for the benefits gained from urban watershed protection. The most effective approach for generating increased protection of surface water resources at the local level is to demonstrate that stewardship will bring significant and lasting benefits to community livability and economic well-being. Restored and protected surface water can improve property values and bring greater public access to amenities that are attractive to residents and many economic investors. By increasing the value that local decision makers place on surface water protection, existing weak local regulations might be strengthened whether the state legislative framework changes or not. Additional research should document local examples of economic benefits that accrue from protecting urban watershed function and surface water quality.

The state and county should enhance outreach to local governmental engineering and planning staff members to ensure that the best land planning and management practices are widely known. The most effective set of practices will address potential surface water degradation during each stage of the land development cycle: protect key resource areas from development, establish buffers to protect resource areas, reduce imperviousness of site design, require limits to the disturbance and erosion of soil during construction, require that quantity and quality of storm water runoff be adequately addressed, and maintain the integrity of the these elements after construction (Schueler 1994). Additional research should identify which communities need the greatest assistance to implement mechanisms and practices in the headwater areas of the region's urban rivers.

The state should create a loan fund to assist local governments in planning, management, and construction activities. Effective construction of facilities to control storm water quantity and quality can dramatically mitigate the adverse effects of land development on stream corridors. More research is needed to identify fiscal impediments to construction of these facilities.

Land use is critical in shaping the status of surface water resources because all forms of land development practices-whether for housing, commercial and industrial, transportation, and recreation uses-can easily contribute to surface water resource degradation (Croke et al. 1973). As the counties around Cuyahoga develop, lack of long-range and integrative perspective would most likely continue the negative consequences to the region's surface water resources. It is critical that the communities in the Ohio's Lake Erie basin vigorously address the relationship between land use, development, and surface water resources soon, to prevent additional damage to northern Ohio's surface water resources and Lake Erie's nearshore areas.

\section{ACKNOWLEDGMENTS}

The author acknowledges the Northeast Ohio Urban Research Consortium of the Ohio Urban University Program and the Urban Center, Maxine Goodman Levine College of Urban Affairs at Cleveland State University for their support for this project. I also thank the reviewers for their very useful guidance during preparation of this article.

\section{REFERENCES}

Adler, R., Landman, J., and Cameron, D. 1993. The Clean Water Act 20 Years Later. Washington, D.C.: Island Press.

Alexander, S. 1993. Clean water in your watershed: a citizens guide to watershed protection. Washington, DC: The Terrene Institute. USEPA funded.

Anonymous. 1996. 10 issues in urban storm water pollution control. American City \& County. 111(10):36-53.

Baker, R. 1976. Controlling land uses and prices by using special gain taxation to intervene in the land market: The Vermont experiment. In Environmental Management: Economic and Social Dimensions, ed. G. Rohrlich, pp.137-155. Cambridge, MA.: Ballinger Publishing Company.

Beach, D. 1993. The Shift and the Shaft? EcoCity Cleveland 1(3):5.

1994. Cuyahoga County: Worrying about sprawl since the 1940s. EcoCity Cleveland 2(2):9.

Beatley, T. 1994. Ethical Land Use: Principles of Policy and Planning. Baltimore and London: The John Hopkins University Press.

Bendor, J. 1985. Parallel Systems: Redundancy in Gov- 
ernment. Berkeley, Ca.: University of California Press.

Binkley, C., Collins, B., Kanter, L., Alford, M., Shapiro, M., and Tabors, R. 1975. Interceptor Sewers and Urban Sprawl. Lexington, Ma.: Lexington Books.

Boyer, B. 1988. Remedial action planning and environmental conflict. Unpublished manuscript. SUNY at Buffalo Law School, Buffalo, NY.

Calthorpe, P. 1993. The Next American Metropolis: Ecology, Community and the American Dream. New York: Princeton Architectural Press.

Cameron, D., ed. 1995. Healing the waters of greater Cleveland. New York: Natural Resources Defense Council.

Center for the Study of Law and Politics. 1993. Building sustainable communities: An environmental guide for local government. In Land Use: Stewardship and the Planning Process Vol. 10. San Francisco.

Croke, E., Croke, K., Kennedy, A., and Hoover, L. 1973. The relationship between land use and environmental protection. In Land Use and the Environment: An Anthology of Readings, ed. V. Curtis, pp. 69-88. Chicago: American Society of Planning Officials.

Curtis, V., ed. 1973. Land Use and the Environment: An Anthology of Readings. Chicago: American Society of Planning Officials.

Devilbiss, C. 1994. A Review of selected functions of riparian buffer zones and some widths associated with them. Columbus: Ohio Department of Natural Resources.

Dowden, L., and McNurney, J., eds. 1995. Municipal Environmental Compliance Manual. Boca Raton: Lewis Publishers.

Federal Interagency Floodplain Management Taskforce. 1996. Protecting floodplain resources: A guidebook for communities, 2 nd ed. Washington, D.C. and Syracuse, NY: Federal Emergency Management Agency/State University of New York College of Environmental Science and Forestry.

Gale, D. 1992. Eight state-sponsored growth management programs: A comparative analysis. Journal of the American Planning Association 58(4):425-439. Chicago, Ill.: American Planning Association.

Godschalk, D., Brower, D., Herr, D., and Vestal, B. 1978. Responsible Growth Management: Cases and Materials. Chapel Hill: Center for Urban and Regional Studies, University of North Carolina.

Great Lakes Science Advisory Board. 1978. The Ecosystem Approach. Windsor, Ontario: The International Joint Commission.

Griggs, G., and Gilchrist, J. 1983. Geological Hazards, Resources and Environmental Planning. Belmont, Ca.: Wadsworth Publishing Co.

Hall, B. 1991. Green Index: A State-by-state Guide to the Nation's Environmental Health. Durham, N.C.: Institute for Southern Studies, Duke University.

IJC (International Joint Commission). 1982. First bien- nial report. Windsor, Ontario: International Joint Commission.

1987. Great Lakes water quality board 1987 report on Great Lakes water Quality. Windsor, Ontario: International Joint Commission.

Jacobs, H. 1989. Localism and land use planning. Journal of Architectural and Planning Research 6:1-17.

Jessup, D. 1990. Guide to State Environmental Programs, 2nd ed. Washington, D.C.: Bureau of National Affairs.

Kaiser, E., Elfers, K., Cohn, S., Reichert, P., Hufschmidt, M., and Stanland, R. 1973. Land use planning: The cornerstone of local environmental planning and control. In Land Use and the Environment: An Anthology of Readings, ed. V. Curtis, pp.103-106. Chicago: American Society of Planning Officials.

Kellogg, W. 1993. Ecology and community in the Great Lakes Basin: The role of citizen advisory committees in environmental planning process. Ph.D. dissertation, Cornell University, Ithaca, NY.

Keyes, D. 1976. Land Development and the Natural Environment: Estimating Impacts. Washington, D.C.: The Urban Institute.

Kivell, P. 1993. Land and the City: Patterns and Processes of Urban Change. London and New York: Routledge.

Kuntsler, J. 1993. The Geography of Nowhere: The Rise and Decline of America's Man-Made Landscape. New York: Simon \& Schuster.

Lang, R., and Brooks, A. 1987. Integrating water quality considerations with land use planning in the Great Lakes Basin. Occasional Paper Series Understanding Great Lakes Issues. Buffalo: Great Lakes Program/SUNY at Buffalo, Buffalo, NY.

McHarg, I. 1969. Design with Nature. Garden City, N.J.: Doubleday/Natural History Press.

Molnar, J., and Rogers, D. 1982. Interorganizational Coordination in Environmental Management: Process, Strategy, and Objective. In Environmental Policy Implementation, ed. D. Mann, pp. 95-108. Lexington, MA: Lexington Books.

Nonpoint Source Pollution Control Task Force. 1983. Nonpoint source pollution abatement in the Great Lakes Basin: An overview of post-PLUARG developments. Windsor: International Joint Commission.

Odum, W. 1982. Environmental degradation and the tyranny of small decisions. BioScience 32(9): 728-729.

Ohio DNR (Department of Natural Resources). 1996. The coastal zone management act and Ohio: A state, local and federal partnership for balanced resource management. Columbus, Ohio.

Ohio EPA (Environmental Protection Agency). 1994. Stream protection policy fact sheet and supporting material. Columbus, Ohio. 
1997. Lake Erie lakewide management plan concept paper. URL http://chagrin.epa.ohio.gov/ohio lamp/concept.html.

PLUARG (Pollution from Land Use Activities Reference Group). 1978. Environmental Management Strategy for the Great lakes System. Final Report to the International Joint Commission. Windsor, Ontario: International Joint Commission

Redding, M., and Parry, B. 1973. Land use: A vital link to environmental quality. In Land Use and the Environment: An Anthology of Readings, ed. V. Curtis, pp. 3-39. Chicago: American Society of Planning Officials.

Rossmiller, R. 1995. Planning can lower flood insurance costs. American City \& County 110(3):15-16.

Royal Commission on the Future of the Toronto Waterfront. 1992. Regeneration: Toronto's Waterfront and the Sustainable City: Final Report. Toronto, Ontario: Minister of Supply and Services Canada.

Schueler, T. 1994. The stream protection approach: Guidance for developing effective local nonpoint source control programs in the Great Lakes region. Silver Spring, MD: Center for Watershed Protection.

Simonds, J. 1978. Earthscape: A Manual of Environmental Planning and Design. New York: Van Nostrand Reinhold.

Steiner, F. 1991. The Living Landscape: An Ecological Approach of Landscape Planning. New York: McGraw-Hill, Inc.

Thompson, P. 1989. Poison Runoff. New York: Natural Resources Defense Council.

U.S. Bureau of the Census. 1962. County and City Data Book. Washington, D.C. D.C.

1977 County and City Data Book. Washington,

1980. U.S. Census. Washington, D.C.

1990. U.S. Census. Washington, D.C.

USEPA (Environmental Protection Agency). 1990. Environmental monitoring and assessment program (EMAP): Ecological indicators. Washington, D.C.:
U.S. Government Printing Office. EPA/600/3$90 / 060$.

1993a. Lake Erie Lakewide Management Plan

(Fact Sheet) [online]. University Center, Mich: Consortium for International Earth Science Information (CIESIN). URL: http://epaserver.ciesin.org/glreis/ glnpo/prog/lamps/onepgfacts/lkerifct.html.

$1993 \mathrm{~b}$. The watershed protection approach:

Annual report 1992. Office of Water, Washington, DC. EPA-840-S-93-001.

1994. Environmental planning for small communities: A Guide for local decision-makers. Center for Environmental Research Information/Office of Research and Development, Cincinnati, Ohio. EPA/625/R-94/009.

1995. Nonpoint source program and grants guidance. Washington, DC: Office of Water.

USEPA/EC (Environment Canada). 1995. State of the Great Lakes. Chicago: Great Lakes National Program Office.

Visconsi, G. 1994. An inventory of state environmental review policies. MS of Urban Studies Exit Project, College of Urban Affairs, Cleveland State University, Cleveland, Ohio.

Water Planning Agency. 1984. Report to Congress: Nonpoint source pollution in the U.S. Washington, D.C.: United States Environmental Protection Agency.

Wiltshire, S. 1994. Nonpoint source pollution control. In The Clean Water Act Handbook, ed. P. Evans, pp. 245-258. Chicago: American Bar Association/ Section of Natural Resources, Energy and Environmental Law.

Yaro, R., Arendt, R., Dodson, H., and Brabec, E. 1993. Dealing with Change in the Connecticut River Valley: A Design Manual for Conservation and Development. Cambridge, MA: Lincoln Institute of Land Policy. 